\title{
A reális és irreális testsúlycélok motivációs szerepe a fogyásban
}

\author{
A kognitív viselkedésterápiás testsúlycsökkentő programok \\ tapasztalatai
}

\author{
Perczel-Forintos Dóra dr. ${ }^{1}$ - Kohlné Papp Ildikó dr. ${ }^{1}$ \\ Vizin Gabriella dr. ${ }^{1,2}$ - Kiss-Leizer Márton ${ }^{1}$
}

\author{
${ }^{1}$ Semmelweis Egyetem, Általános Orvostudományi Kar, Klinikai Pszichológia Tanszék, Budapest \\ ${ }^{2}$ Eötvös Loránd Tudományegyetem, Pedagógiai és Pszichológiai Kar, Pszichológiai Intézet, Budapest
}

Bevezetés: Az elhízás korunk egyik legnagyobb kihívása, hiszen a többletsúly számos krónikus betegség kockázati tényezője, és fontos pszichés és szociális következményei vannak. A kezelésben bizonyítottan hatékony a kognitív viselkedésterápiás testsúlycsökkentő program, amelynek során alapvető fontosságú a reális célsúly meghatározása, ugyanis az irreális elvárások megakadályozhatják a hosszú távú sikeres testsúlykontrollt.

Célkitüzés: Prospektív kutatásunk kérdése, hogy az elérhető fogyást milyen mértékben befolyásolják a testsúlycélok a kognitív viselkedésterápiás testsúlycsökkentő program során. Feltételeztük, hogy a testsúlycsökkentő csoport résztvevői irreális fogyási elvárásokkal érkeznek, melyek azonban reálisabbá válnak a program végére, és megmaradnak az utánkövetés idejére. Emellett feltételeztük, hogy a testsúlycsökkentő program során az evési magatartás pozitív irányban fog változni.

Módszer: A 24 hetes testsúlycsökkentő programban 63, az egyéves utánkövetésben pedig 49 felnőtt vett részt. A résztvevők antropometriai mutatói mellett (testtömeg, testmagasság) az evési magatartást és a testsúlycélokat a Háromfaktoros Evési Kérdőívvel, illetve a Célok és Relatív Testsúlyok Kérdőívvel mértük fel.

Eredmények: A résztvevők közel 90\%-a elérte a professzionális testsúlycsökkentő módszerek esetében elvárható legalább 5-10\%-os fogyást, az evési magatartás pozitív irányban változott, testsúlycéljaik reálisabbak lettek. A fogyás szignifikáns, fordított kapcsolatban volt az aktuális és az álomsúly, az aktuális és a vágyott, valamint az aktuális és az elfogadható testsúly közötti eltéréssel.

Következtetés: A kognitív viselkedésterápia széles körben alkalmazható, hatékony testsúlycsökkentő módszer, amelynek sikerében fontos szerepet játszanak a reálisan kitûzött testsúlycélok.

Orv Hetil. 2021; 162(28): 1119-1128.

Kulcsszavak: testsúlycsökkentő program, testsúlycélok, motiváció, evési magatartás, életmódváltozás, kognitív viselkedésterápia, hatékonyság

\section{The motivational role of realistic and unrealistic weight targets in body-weight loss}

\section{Experiences with a cognitive behavioral body-weight loss program}

Introduction: Obesity has become one of the most challenging issues, as the excess body-weight is a risk factor for numerous chronic diseases and has serious psychological and social consequences. The cognitive behavioral approach to weight loss had been shown an effective treatment, in which realistic weight target setting is essential, because unrealistic expectations can hinder the effort for a successful long-term weight management.

Objective: The objective of our prospective study was to investigate as to how weight loss is influenced by realistic and unrealistic weight targets in a cognitive behavioral weight loss program. We hypothesized that the participants come with unrealistic weight loss expectations, which become more realistic by the end of the program and remain realistic for the follow-up. In addition, a positive change was expected in the eating behavior of the participants during the program.

Method: The program was completed by 63 people, 49 subjects participated in the 1-year follow-up. Anthropometric data were obtained and the participants were asked to fill in the Three-Factor Eating Questionnaire - Revised 21 items and the Goals and Relative Weights Questionnaire. 
Results: According to the results, the program is effective, since nearly $90 \%$ of the participants reached at least $5-10 \%$ weight loss as expected by professional weight loss methods. Besides weight loss there were positive changes in the participants' eating behavior; weight targets became more realistic. Weight loss was inversely related to the difference between actual and dream, actual and desired as well as between actual and acceptable weight.

Conclusion: Our results in accordance with previous studies show that cognitive behavioral weight loss programs can be effective; however, setting up realistic weight targets can be crucial in successful weight loss.

Keywords: body-weight loss program, body-weight goals, motivation, eating behavior, lifestyle change, cognitive behavioral therapy, effectiveness

Perczel-Forintos D, Kohlné Papp I, Vizin G, Kiss-Leizer M. [The motivational role of realistic and unrealistic weight targets in body-weight loss. Experiences with a cognitive behavioral body-weight loss program]. Orv Hetil. 2021; 162(28): 1119-1128.

(Beérkezett: 2020. december 6.; elfogadva: 2021. január 16.)

\begin{abstract}
Rövidítések
$\mathrm{BMI}=($ body mass index $)$ testtömegindex $; \mathrm{COMM}=($ clinical obesity maintenance model) a klinikai elhízás fenntartásának modellje; ETT TUKEB = Egészségügyi Tudományos Tanács, Tudományos és Kutatásetikai Bizottság; TFEQ-R21 = $($ ThreeFactor Eating Questionnaire-R21) a 21 tételes Háromfaktoros Evési Kérdőív
\end{abstract}

Az elhízás korunk egyik nagy kihívása, mely súlyos terhet jelent az egyénre és a társadalomra egyaránt. A jelenség hazánkban is komoly egészségügyi probléma, az Egészségügyi Világszervezet legfrissebb [1], 2016. évi felmérése alapján Magyarországon a férfiak $67 \%$-a, a nők 54\%-a túlsúllyal (testtömegindex, body mass index, $\mathrm{BMI}^{1}=$ 25-29,9) vagy elhízással (BMI $\geq 30)$ él, amivel hazánk a világranglista 41 . helyén áll. Amellett, hogy az elhízás nyilvánvaló testi következményekkel jár, és számos krónikus megbetegedés kockázati tényezője, fontos pszichés és szociális hatásai is vannak. A többletsúllyal élők körében az átlagnépességhez képest gyakoribbak a hangulatzavarok [2], a szorongásos betegségek, a falásrohamok, az alacsony önértékelés [3] és az életminőség csökkenése [4].

Közismert, hogy a nyugati kultúrában negatív attitüdök kapcsolódnak az elhízáshoz. A kutatási eredmények alapján a stigmatizáció jelensége masszív, kifejezett és átható a túlsúllyal küzdők körében, így nagyon nehéz megváltoztatni [5]. A többletsúly jeleit gyakran erkölcsi gyengeségként értelmezik, így aki nem tesz ellene, az lenézhető, elítélhető. Bizonyított, hogy az elhízással élő emberek hátrányt szenvednek az egészségügyben, az oktatásban, az interperszonális kapcsolatokban, valamint a foglalkoztatásban is, hiszen ezeket az alkalmazottakat általában lustának és kevésbé kompetensnek ítélik meg [6]. A negatív attitúdök már gyermekkorban kialakulhat-

\footnotetext{
${ }^{1}$ A BMI kiszámítása: a kg-ban kifejezett testtömeg és a méterben mért testmagasság négyzetének hányadosa $\left(\mathrm{BMI}=\mathrm{kg} / \mathrm{m}^{2}\right)$.
}

nak, az előítéletek pedig a serdülőkor felé haladva csak tovább erősödnek [7]. Az utóbbi évek kutatási eredményei alapján a diszkrimináció tovább növeli az elhízás veszélyét, az elhízással élők pedig gyakran maguk is internalizálják a karcsúságideált és az elhízottakra vonatkozó negatív attitűdöket [8]. A hazánkban végzett felmérések alapján a magyarok is meglehetősen elégedetlenek a különböző testrészeikkel és az alakjukkal, és már a 10-15 év közötti gyermekek körében is jelen van a túlsúlyos kortársaik elítélése [9]. Söt, gyakran maguk a túlsúllyal küzdő gyermekek is elítélik az elhízással élő kortársaikat, azaz szintén negatív attitüddel rendelkeznek a többletsúllyal élők felé [10]. Összességében megállapítható, hogy a mai társadalomban tapasztalható és széles körben elfogadott, elhízottakkal szembeni elöítélet fontos szerepet játszhat a testsúlyzavarokkal küzdő személyek mentális egészségének alakulásában.

\section{A testsúlycélok szerepe}

Mivel mind a fejlett, mind a fejlődő országokban jelentősen megnövekedett a túlsúly, illetve az elhízás aránya minden életkorban [11], az elhízás gondozása és kezelése sokkal több mindenre ki kell, hogy terjedjen, mint a testsúlycsökkentés: a cél az általános egészségi állapot javítása, a kockázati tényezők felismerése, valamint a szövődmények kezelése [12]. A sikeres testsúlycsökkentés eléréséhez alapvető fontosságú olyan mértékű fogyás meghatározása, amelynek elérésével mérsékelhetjük az elhízást kísérő betegségek kialakulásának kockázatát, és amely reálisan megvalósítható. Ezt nevezzük reális célsúlynak. Egybehangzó szakirodalmi adatok szerint az I. fokú elhízás (BMI = 30-35) esetén egy kognitív viselkedésterápiás testsúlycsökkentő programmal 5-10\% testtömegcsökkenés tekinthető reális célnak, amely már kedvező hatást gyakorol az egészségi állapotra. Az elhízással élő személyek fogyási célja azonban ezt általában jelentősen meghaladja. A legtöbb személy önkényesen meghatározott, túlzó elvárásokkal kezd bele a programba, és 
legalább 22-34\% fogyást remél, még abban az esetben is, ha előzetesen tájékoztatják a kezelés során várható eredményekről $[7,13]$. A célsúlyok szerepét az elhízás kezelésében csak kevés kutatás vizsgálja, holott a reális cél kitűzése a fogyás sikerességével és nagyobb fokú adherenciával is együtt jár. Egy kutatásban a fogyás eredményességét vizsgálták reális és irreális célsúlyok fennállása esetén. A hosszú távú, reális célsúlyt kitűző résztvevők súlya a program végére legalább 10\%-kal csökkent, amit az egyéves utánkövetéses időszakban is fenntartottak $[14,15]$. Az irreális célsúly ezzel szemben következetlen étkezési szokásokkal, az önellenőrzés hiányával és összességében a fogyás sikertelenségével járt együtt. A mérsékelt, valósághư cél felállítása tehát fokozza a teljesítményt, növeli az énhatékonyság-érzést, és csökkenti az esetleges sikertelen kezelés negatív hatásait [16, 17].

A reális és a vágyott célsúly közötti túlzott eltérés negatív érzelmi választ alakíthat ki, amelyet jól példáz Ohsiek és Williams [18] vizsgálata. Az említett szerzők szisztematikus, áttekintő tanulmányukban azt találták, hogy a fogyással kapcsolatos túlzó elvárások frusztrációt és reménytelenséget okoznak, ami hosszú távon a kezelés feladásához vagy visszahízáshoz vezet. Dutton és mtsai [19] randomizált kontrollált vizsgálatában az eredmények azt mutatták, hogy az irreális célsúlyokhoz dichotóm gondolkodásmód, érzelmi evés, negatív testkép és depresszív hangulat is kapcsolódott, emellett a résztvevők általában elégedetlenebbek voltak a kezeléssel. Fontos azonban kiemelni, hogy az irreális célsúlyok jelentősen csökkentek azoknál a pácienseknél, akik a kezelés lezárását követően rendszeresen tartották a kapcsolatot a háziorvosukkal [20]. A célsúlyok kitűzése nemcsak a fogyás sikerességét mozdítja előre, de egy összefoglaló tanulmány [21] szerint az egészségmagatartással is együtt jár, hiszen az elérhető célsúly a csökkent szénhidrátbevitel mellett az alkoholfogyasztás és a dohányzás visszaszorításával is járhat. Ezzel ellentétben egy másik randomizált kontrollált vizsgálatban [22] nem találtak kapcsolatot az irreális fogyási célok és a súlycsökkenés között kognitív viselkedésterápiás testsúlycsökkentő csoportban részt vevők és diétázók körében. Az irreális célsúlyok kitűzése szempontjából a fiatal, magasabb kezdő BMI-vel rendelkező nők a legveszélyeztetettebbek: a lemorzsolódási arány 32,3\% volt, amely - az életkort, a kiinduló testsúlyt és a végzettséget kontrollálva - szignifikáns kapcsolatban állt az irreális célsúlyokkal $[23,24]$.

A legtöbb páciensnek több testsúlycélja van: ideális testsúlynak vagy „álomsúlynak” tartják azt, amelyet szeretnének elérni, de nem tartják megvalósíthatónak. Vágyott testsúly, amelyről azt gondolják, hogy elérhető, és elégedettek is lennének vele. Általában a résztvevők számára még elfogadható az a testsúly, amellyel bár nem lennének elégedettek, de elfogadják, hiszen az aktuális testsúlyuknál alacsonyabb: ezt nevezzük elfogadható testsúlycélnak. Végül létezik a „csalódást keltō” testsúly, amely alacsonyabb ugyan a jelenlegi testsúlyuknál, de nem éri el az önmaguktól elvárt mértéket [25]. A külön- féle célsúlyok alakulását egy 48 hetes viselkedésterápiás program során vizsgálták [26], amelyben a 60, elhízással élő résztvevő közül senki nem érte el a vágyott álomsúlyt. A legtöbben min. 32\%-os fogyást reméltek, amely több mint a háromszorosa volt annak, amit a kezelés során elértek. A páciensek 47\%-a még az eredetileg elfogadhatatlanul kevésnek tartott $20 \%$ mértékü fogyást sem tudta elérni, hiszen ez az ô esetükben kb. 17 kg súlycsökkenést jelentett volna. Mindez jól példázza, milyen elérhetetlen célsúlyokkal vágnak neki a programnak a résztvevők, ami ilyenkor az énhatékonyság-érzés csökkenéséhez és maladaptív megküzdési stratégiák alkalmazásához vezet.

\section{Motivációs tényezők}

A fogyni vágyó páciensek általában hiányos ismeretekkel rendelkeznek arról, hogy a fogyás milyen potenciális előnyökkel járhat. Noha közismert a többletsúly egészségi kockázata, a résztvevők az egészség megőrzését, illetve a betegségek megelőzését alig fogalmazzák meg mint okot a testsúly csökkentéséhez. Már 10\%-os testtömegcsökkenés mind statisztikailag, mind klinikailag csökkenti a cukorbetegség, a daganatos kórképek, illetve a cardiovascularis megbetegedések kockázatát, a fogyni vágyók többsége mégis az előnyösebb öltözködés, a jobb megjelenés vagy az önbizalom-növelés érdekében kezd bele a diétába [7, 27-29].

A súlycsökkenés és a testsúlykontroll hátterében álló motivációs tényezők két csoportra oszthatók [30]. A mennyiségi motiváció egyfajta hajlandóságot jelent a fogyásra (mennyit szeretnének fogyni?), a minőségi motiváció pedig arra utal, hogy a személy mit szeretne elérni a fogyás révén. Ezen belül megkülönböztethetünk belső okokat (például egészségnyereség, személyes fejlődés) és külső tényezőket (a társas kapcsolatok javítása, előnyösebb külső elérése). Gow, Baur és Ho kurrens vizsgálata alapján úgy tûnik [31], hogy a súlycsökkentő programok során a korai fogyás, a motiváció és az elköteleződés legerósebb mutatója. Eredményeik alapján a korai, harmadik hónapig elért súlycsökkenés megbízhatóan jelezte előre a súlyvesztés mértékét a 12 . hónapban, ami pedig az alacsony szintű érzelmi evés mellett prediktornak bizonyult a további súlycsökkenés szempontjából a 24 hónapos utánkövetés során. Mindez összekapcsolódik az énhatékonysággal, amely szintén fontos szerepet játszik az elért testsúly megtartásában.

A tudományos kutatások összegzésével egy ausztrál kutatócsoport egységes elméleti keretbe helyezte az elhízás fenntartásában szerepet játszó neuropszichológiai és mentális tényezőket, és kidolgozta az ún. COMM modellt (clinical obesity maintenance model) [32]. A COMM modell szerint az elhízás fenntartásában központi szerepe van a már kialakult, szokványossá vált viselkedésmódoknak. Ennek értelmében, ha egy magatartásforma szokássá válik, bizonyos belső ingerek vagy késztetések hatására automatikusan aktiválódik, így ezek 
megváltoztatásához komoly erőfeszítésre lehet szükség $[33,34]$. Éppen ezért nem lehet alábecsülni a testsúlycélokkal való munkát, hiszen a reális célsúly kitüzése elősegítheti alternatív válaszok megjelenését, mivel ennek kapcsán a résztvevók motiváltabbak arra, hogy 1) a fogyáshoz szükséges tevékenységeket elvégezzék (például az ételadagok csökkentése, futás); 2) végigcsinálják a programot; 3 ) képesek legyenek folyamatosan erófeszítést tenni, és 4) további ismereteket szerezzenek a súlycsökkenés egészségre előnyös hatásairól [21].

A visszahízás megelőzése érdekében ezen túlmenően hosszú távú súlymegtartó programot is ki kell dolgozni, hiszen fontos, hogy a személy számára világos legyen: az elhízás krónikus betegség, ezért a kezelésének élethoszszig kell tartania [29].

\section{Kezelési lehetőségek}

A túlsúly $(\mathrm{BMI}=25-29,9)$ és az I. (BMI = 30-34,9), valamint a II. fokú $(\mathrm{BMI}=35-39,9)$ elhízás esetén a beavatkozási lehetőségek egyik alappillére a kognitív viselkedésterápia. Ennek célja, hogy azonosítsa és korrigálja azokat a maladaptív szokásokat, amelyek hozzájárulnak a páciens testsúlyzavaraihoz, illetve a testsúlycsökkentő próbálkozások kudarcához [35]. A bázisterápia további pillérei a diétaterápia, valamint a mozgásterápia, amely szükség esetén gyógyszeres terápiával egészülhet ki. Mindezek mellett III. fokú $(B M I \geq 40)$ elhízásban vagy II. fokú elhízásban szövődményes betegségek esetén sebészeti megoldások is nélkülözhetetlenné válnak [36, 37]. Az elhízásnak a bizonyítékokon alapuló kognitív viselkedésterápiája általában 10-15 fós csoportokban történik, heti egy alkalommal, általában 24-26 héten át $[7,29,38]$. A programokra jellemző, hogy nagymértékben strukturáltak, időhatárosak, kezelési alapelveik világosan áttekinthetők, az ülések menete pedig protokoll

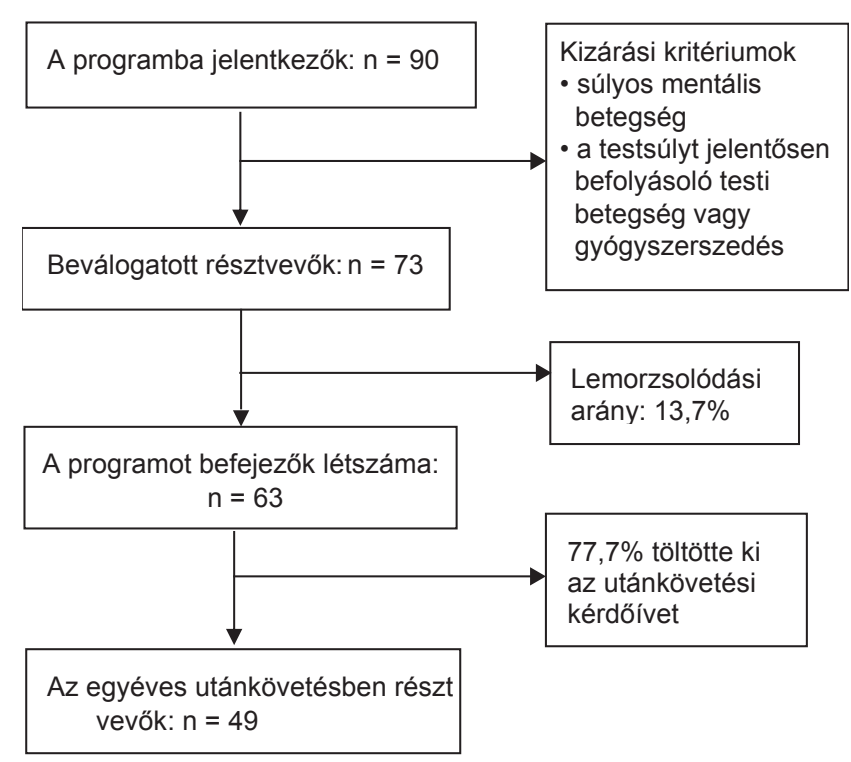

1. ábra | Folyamatábra a vizsgálatban részt vevőkról alapján történik [29]. Hatékonyságvizsgálatok metaanalízise alapján a kognitív viselkedésterápia hat hónap alatt mérsékelt, átlagosan 7-10\%-os fogyást eredményez [19]. A hosszú távú követéses vizsgálatok eredményei nem ennyire kedvezőek: az elért testsúlyt általában 12 hónapon keresztül megtartják a résztvevők, ezt követôen a leadott súly kb. 30-40\%-át sokan visszahízzák, a páciensek többsége 3 éven belül viszont újra eléri a kezdeti testtömegét [39-42]. Ennek hátterében fontos szerepet játszanak az irreális fogyási célok és a fogyáshoz társuló másodlagos elvárások a személyes boldogulást, boldogságot vagy a munkaerőpiacon történő könnyebb elhelyezkedést illetően [13].

\section{Célkitüzések}

A fentiek alapján kutatásunk arra irányult, hogy a jelenleg leginkább elfogadott kognitív viselkedésterápiás testsúlycsökkentő programmal elérhető fogyást a testsúlycélok milyen mértékben befolyásolják. Feltételeztük, hogy minél reálisabb célsúlyt tûz ki a személy, annál valószínúbb, hogy eléri. Ezzel szemben minél irreálisabb testsúlycélt tűz ki, annál kisebb az esélye arra, hogy elérje. Másrészt feltételeztük, hogy a testsúlycsökkentő csoport résztvevői irreális fogyási elvárásokkal érkeznek, melyek azonban reálisabbá válnak a program végére, és megmaradnak az utánkövetés idejére, ezzel elősegítve az elért eredmény fenntartását. A hatékonyságot a testsúly és a testtömegindex változása mellett az evési magatartás jellemzőinek nyomon követésével is felmértük. Ennek megfelelően feltételeztük, hogy a testsúlycsökkentő program során az evési magatartás pozitív irányban fog változni, azaz növekszik a kognitív korlátozás, és csökken a kontrollálatlan evés, valamint az érzelmi evés. Elvárásaink szerint ez a javulás fennmarad a program lezárása után egy évvel is.

\section{Módszer}

Résztvevők: a kognitív viselkedésterápiás testsúlycsökkentő programban 25-70 év közötti, túlsúllyal, illetve elhízással élők vettek részt. Az érdeklődők háziorvos javaslatára vagy hirdetés alapján, önként jelentkeztek a csoportba. Kizárási kritérium volt a súlyos mentális betegség (például súlyos depresszió, személyiségzavar, akut pszichotikus állapot), valamint a testsúlyt jelentősen befolyásoló testi betegség (például pajzsmirigybetegség), illetve ilyen gyógyszerek szedése. Négy év alatt összesen nyolc viselkedésterápiás testsúlycsökkentő csoportot vezettünk, átlagosan 10 (8-12) fővel. A 90 jelentkezőből összesen 73 fó került be a testsúlycsökkentő csoportokba; ebből 63 személy teljesítette a programot, így a lemorzsolódás aránya 13,7\%, ami kedvezőnek tekinthető. Az utánkövetés során 49 személy küldte vissza az e-mailben kiküldött utánkövetési kérdőívet, ami 77,7\%-os arány. A programot tehát 63 személy, 19 férfi és 44 nő teljesítette (1. ábra). 
1. táblázat Szociodemográfiai és tápláltsági állapotra vonatkozó adatok az egyéves utánkövetésben is részt vevő́k mintáján

\begin{tabular}{llc}
\hline Változók & & $\begin{array}{c}\text { Az utánkövetésben } \\
\text { részt vevők }(\mathrm{n}=49)\end{array}$ \\
\hline Életkor (év) - átlag (SD) & $42,7(11,70)$ \\
\hline Nem & Férfi & $16(32,7 \%)$ \\
$\mathrm{n}(\%)$ & Nő & $33(67,3 \%)$ \\
\hline Családi állapot & Nőtlen, hajadon & $10(20,4 \%)$ \\
$\mathrm{n}(\%)$ & Élettársi kapcsolatban él & $6(12,2 \%)$ \\
& Házas & $27(55,1 \%)$ \\
& Elvált & $6(12,2 \%)$ \\
\hline Iskolai végzettség & Alapfokú & $1(2,0 \%)$ \\
$\mathrm{n}(\%)$ & Középfokú & $20(40,8 \%)$ \\
& Felsőfokú & $28(57,1 \%)$ \\
\hline Lakóhely & Budapest & $44(89,8 \%)$ \\
$\mathrm{n}(\%)$ & Vidék & $5(10,2 \%)$ \\
\hline Testtömeg a kiinduláskor $(\mathrm{kg})-$ átlag $(\mathrm{SD})$ & $111,1(25,74)$ \\
\hline BMI a kiinduláskor $\left(\mathrm{kg} / \mathrm{m}^{2}\right)$ - átlag (SD) & $37,2(7,17)$ \\
\hline
\end{tabular}

$\mathrm{BMI}=$ testtömegindex $; \mathrm{SD}=$ standard deviáció

A testsúlycsökkentő csoportban a résztvevők átlagéletkora 42,1 év, testsúlyuk átlaga 110,4 kg, BMI-átlaguk 37,3 volt; az utánkövetésben 49 fó vett részt (1. táblázat). A program során a testsúlymérésre, illetve a kérdőívcsomag kitöltésére az első alkalommal és a program végén, a 24. héten került sor, személyesen, a csoportüléseket megelőzően. A program lezárását követő 12. hónapban e-mail formájában küldtük ki a kérdőívcsomagot, amelyben rákérdeztünk a résztvevők testsúlyára is. A kérdő́vek felvételére és a kutatásban való felhasználására szóbeli és írásbeli tájékoztatás után, a résztvevők írásos beleegyezésével, illetve az etikai engedély birtokában került $\operatorname{sor}^{2}[7,43]$.

\section{Méróeszközök}

Alapadatok: a demográfiai adatok közül a nemre, az életkorra, a családi állapotra, az iskolai végzettségre és a lakóhelyre kérdeztünk rá. A testtömeg $(\mathrm{kg})$ és a testmagasság $(\mathrm{cm})$ a program elején és a program végén objektív méréssel történt, felsőruházatban, cipő nélkül. Az utánkövetés során az antropometriai adatokat önbeszámolóval nyertük. A tápláltsági állapot meghatározására a nemzetközileg elismert, kor- és nemspecifikus BMI-kategóriák alapján került sor $[44,45]$.

Testsúlycélok: a motiváció felmérése egyrészt nyitott kérdések formájában történt. Megkértük a résztvevőket, hogy sorolják fel azt a három legfontosabb okot, amiért fogyni szeretnének, másrészt kitöltettük a Célok és Relatín Testsúlyok Kérdöívet [26], amely négy itemből áll.

2 ETT TUKEB 38/2012
A személynek kilogrammban kell meghatároznia, mit tart álomsúlynak („Az a testsúly, amelyet akkor választana, ha olyan súlya lehetne, amilyet csak akar"), örvendetes súlynak („Ez a testsúly nem tenné Önt különösebben boldoggá, de amelyet el tudna fogadni, mivel alacsonyabb, mint a jelenlegi súlya”), elfogadható súlynak, végül csalódást keltő súlynak („Olyan testsúly, amely alacsonyabb ugyan a jelenlegi testsúlyánál, de semmiképpen nem tartaná sikeresnek. Csalódott lenne, hogyba ez lenne a súlya a súlycsökkentő kezelés után”). Az elemzés során az aktuális testtömegből kivonva az egyes célsúlyokat, majd elosztva az aktuális testsúllyal és e hányadost százzal megszorozva képeztük az adott célsúly eléréséhez szükséges fogyás mértékét reprezentáló változót: ([aktuális testtömeg adott célsúly] / aktuális testtömeg) × 100 .

21 tételes Háromfaktoros Evési Kérdōin (TFEQ-R21) [46]. Az önbeszámolós kérdőív három alskálából áll. A Kognitín korlátozás alskála az arra való hajlamot méri fel, hogy mennyire korlátozza a személy tudatosan a táplálékbevitelét annak érdekében, hogy befolyásolja a testsúlyát vagy az alakját. A második és a harmadik alskála az érzelmi evést és a kontrollálatlan evést méri fel. A magasabb pontszám az adott evési magatartásra való nagyobb tendenciát jelzi. A kérdőív belső megbízhatósága a jelen mintán elfogadhatónak bizonyult: a skálák Cronbach- $\alpha$ mutatója 0,61-0,94 közötti értéket vett fel a három adatfelvétel során.

\section{Az önsegítő elemekkel kiegészített viselkedésterápiás testsúlycsökkentő program váza}

A kis létszámú, 8-12 fős csoportos foglalkozásokat 24 héten át tartottuk heti rendszerességgel kétórás időtartamban. A csoportokat a második szerző (K. P. I.) vezette. Az önsegítést fokozatosan vezettük be, ennek megfelelően az első 8 héten minden alkalommal, a második 8 héten kéthetente, az utolsó 8 hetes blokkban pedig már csak havonta vettünk részt a foglalkozásokon; a többi ülés során a csoport önsegítő csoportként múködött. A tematika hagyományos viselkedésterápiás elemekre épült (reális célok felállítása, önmonitorozás, stimuluskontroll, problémamegoldó készségek, asszertív készségek, stresszmenedzsment, relaxációs technikák, relapsusprevenció), amelyeket kognitív elemekkel bővítettünk (fogyást és testsúlytartást befolyásoló kognitív torzítások, a gondolatnapló alkalmazásának elsajátítása, az önértékelés és a testkép kapcsolatának konceptualizálása) $[7,29,34,43]$.

\section{Statisztikai elemzések}

Az elemzéseket az SPSS 22 (IBM Corporation, Armonk, NY, Amerikai Egyesült Államok) és a ROPstat statisztikai programcsomagokkal végeztük. A kérdőívek skáláinak belső megbízhatóságának becslésére Cronbach- $\alpha$ 
mutatókat számítottunk. Az időbeli változások felmérésére diszkrét változók esetében Cochran-féle Q-próbát, míg folytonos változók esetében két szempontos vegyes varianciaanalízist és robusztus két szempontos varianciaanalízist alkalmaztunk. Az utóelemzéseket az átlagok Tukey-féle, páronkénti összehasonlításának segítségével elemeztük. A program során elért százalékos fogyás kiszámítására a következő képletet alkalmaztuk: ([program eleje - program vége] / program eleje) $\times 100$. A testsúlytartás százalékos arányának kiszámítására a következő képletet alkalmaztuk: ([program vége - 1 éves utánkövetés] / program vége $) \times 100$.

\section{Eredmények}

\section{A testsúly változása}

Testsúlycsökkenés a program során (0-6. hónap): a program során a csoporttagok $(\mathrm{n}=63)$ átlagosan 10,1 kg-ot fogytak, ami a kiindulási testtömeg 9,0\%-ának felel meg. A résztvevők $88,9 \%$-ának súlycsökkenése elérte a legalább 5-10\%-ot, ezen belül 28,6\%-uk fogyása meghaladta a $10 \%$-ot.

Testsúlycsökkenés a program és az utánkövetés során (0-18. hónap): a válaszadók $(\mathrm{n}=49)$ a program elején mérthez képest átlagosan 10,5 kg-mal voltak könnyebbek, ami átlag 9,2\%-os súlycsökkenésnek felel meg. A résztvevők 75,0\%-ánál jelent meg legalább 5-10\%-os súlycsökkenés a program elején mért testtömeghez képest, ezen belül $35,4 \%$-uk súlycsökkenése meghaladta a $10 \%$-ot.

A testsúlytartás a program vége és az utánkövetés között (6-18. hónap): a program lezárása és az utánkövetés között a személyek átlagosan $0,27 \mathrm{~kg}$-ot fogytak, ami átlag 0,24\%-os fogyásnak felel meg; 36,7\%-uk meg tudta tartani a program végére elért fogyást. Ezenkívül 22,1\%uk testsúlya tovább csökkent a program lezárása után, 4 fó pedig további $10 \%$-ot fogyott.

$\mathrm{Az}$ ismételt méréses varianciaanalízisek eredményei szerint a testtömeg $(\mathrm{F}[1,3 ; 62,0]=45,792 ; \mathrm{p}<0,001)$ és a $\mathrm{BMI}(\mathrm{F}[2,96]=49,550 ; \mathrm{p}<0,001)$ is szignifikánsan csökkent a vizsgálat időtartama alatt. A 2. és 3. ábrán szemléltetjük a testsúlycsökkentő program előtt, a befejezéskor és az egyéves utánkövetésnél a kérdő́iveket kitöltó résztvevők $(n=49)$ testtömegének és BMI-jének átlagát.

\section{A testsúlycélok változása}

A résztvevők testsúlycéljainak meghatározásához az aktuális testtömegtől való eltérés százalékos átlagát a következő képlettel számoltuk ki: ([aktuális testtömeg adott célsúly] / aktuális testtömeg) $\times 100$.

A legnagyobb én-énideál diszkrepancia az álomsúly $(32,9 \%)$ és a vágyott súly $(26,0 \%)$ tekintetében mutatkozott mindhárom idôpontban (mérési ponton). Megfigyelhető, hogy habár mind az álomsúlyra, mind a vágyott súlyra vonatkozóan jelentősen csökkentek a test-

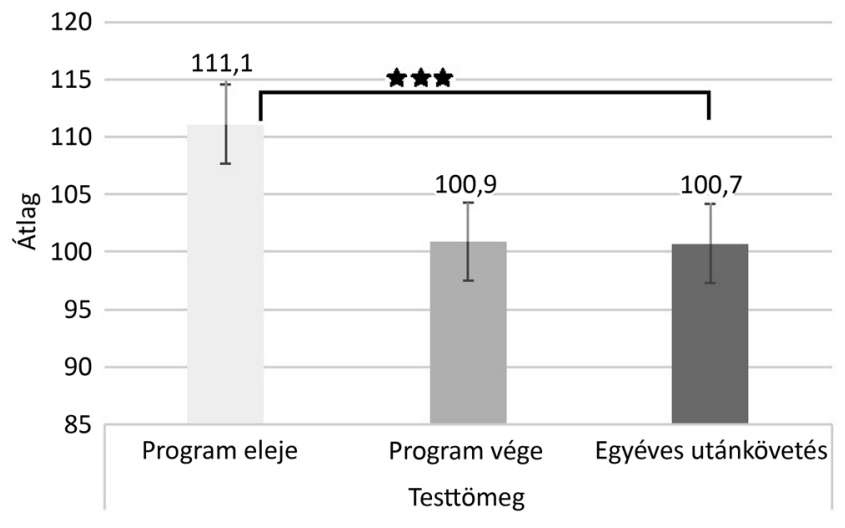

2. ábra $\mid$ A testtömeg változása a testsúlycsökkentő program előtt, a befejezéskor és az egyéves utánkövetésnél a kérdőíveket mindhárom időpontban kitöltő résztvevők körében $(n=49)$

Megjegyzés: ${ }^{* * *} \mathrm{p}<0,001$

Az ábrán feltüntettük az átlagok 95\%-os megbízhatósági intervallumát

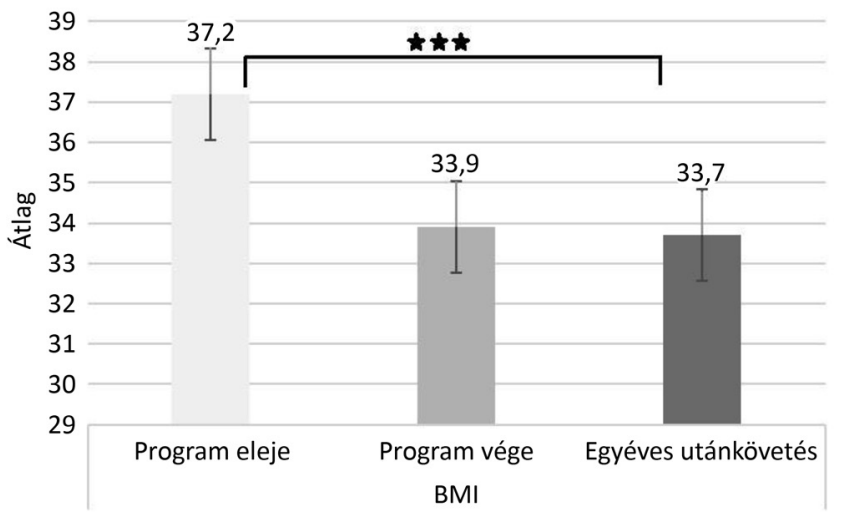

3. ábra

A BMI-értékek változása a testsúlycsökkentő program előtt, a befejezéskor és az egyéves utánkövetésnél a kérdőíveket mindhárom időpontban kitöltő résztvevők körében $(n=49)$

Megjegyzés: *** $\mathrm{p}<0,001$

Az ábrán feltüntettük az átlagok 95\%-os megbízhatósági intervallumát

$\mathrm{BMI}=$ testtömegindex

súlycélok (fogyási célok), a program végére és az utánkövetés idejére is irreális mértékúek maradtak. Az elfogadható testsúlyra vonatkozó fogyási cél mindhárom mérési ponton elérte a $10 \%$-ot, a program elejéhez képest azonban itt is jelentôs csökkenést tapasztalhatunk. A csalódást keltő fogyás mértéke a program elején átlagosan $8 \%$ volt, ez azonban a program végére és az utánkövetés idejére jelentősen mérséklődött.

$\mathrm{Az}$ ismételt méréses varianciaanalíziseknek, illetve a robusztus két szempontos varianciaanalíziseknek és ezek utóelemzéseinek eredményei szerint valamennyi célsúly eléréséhez szükséges fogyás mértékében szignifikáns csökkenés mutatkozott a program kezdete és vége között, amely tartósan megmaradt az utánkövetés idejére is (álomsúly: $\mathrm{F}[2,88]=31,681 ; \mathrm{p}<0,001$; vágyott súly: $\mathrm{F}[1,7 ; 75,0]=38,550 ; \mathrm{p}<0,001 ;$ elfogadható súly: 

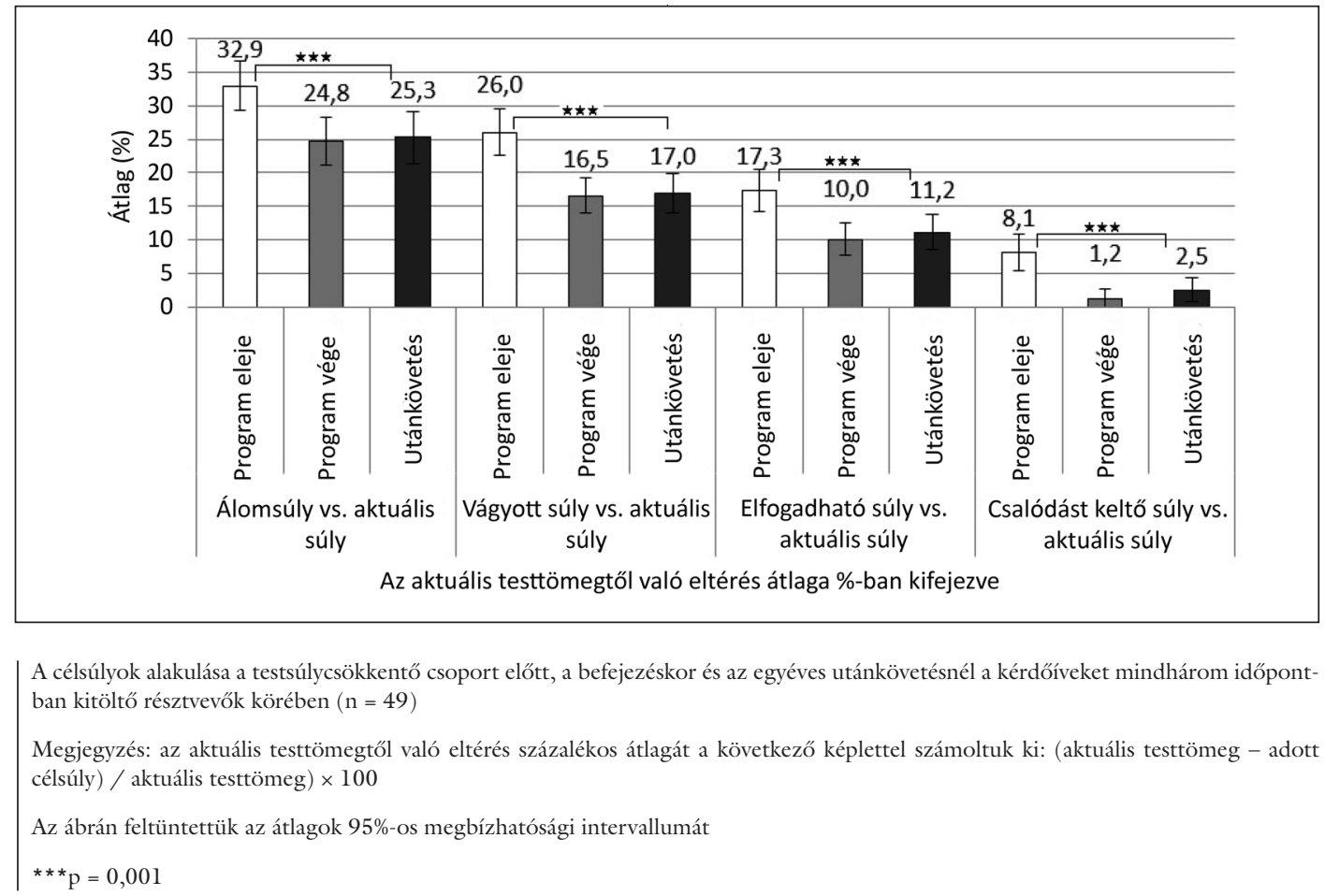

$\mathrm{F}[2,88]=19,044 ; \mathrm{p}<0,001 ;$ csalódást keltő súly: $\mathrm{F}[1,6$; $68,3]=15,099 ; \mathrm{p}<0,001)$.

A korrelációs elemzés eredményei szerint a program végén mért aktuális és álomsúly, aktuális és vágyott, valamint aktuális és elfogadható testsúly közötti százalékos eltérés szignifikáns, fordított kapcsolatban volt a program végére elért fogyás mértékével (álomtestsúly: $\mathrm{r}=$ $-0,42 ; \mathrm{p}=0,001 ;$ vágyott testsúly: $\mathrm{r}=-0,42 ; \mathrm{p}=0,001$; elfogadható testsúly: $\mathrm{r}=-0,33 ; \mathrm{p}=0,009)$. A tendencia az utánkövetés során is megjelenik: a felmért célsúlyok esetében szintén az látható, hogy az utánkövetés során vizsgált százalékos fogyás szignifikáns, fordított kapcso-

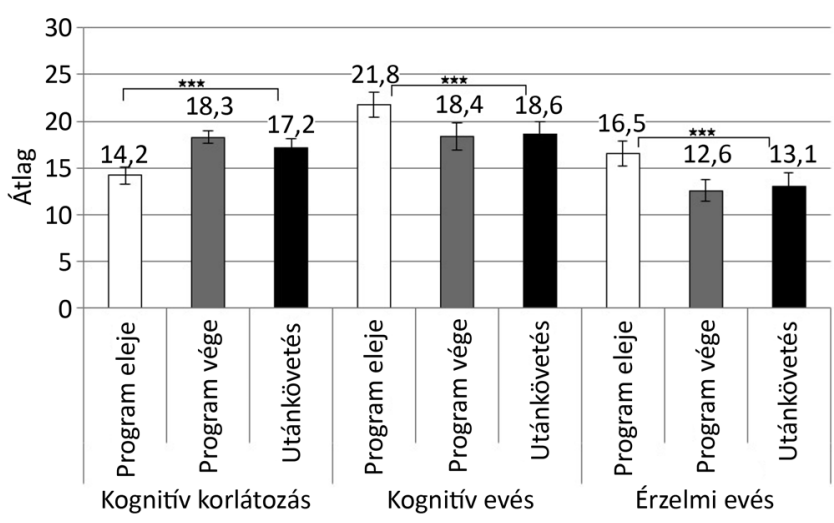

5. ábra

Az evési magatartások alakulása a testsúlycsökkentő csoport előtt, a befejezéskor és az egyéves utánkövetésnél a kérdőíveket mindhárom időpontban kitöltő résztvevők körében $(\mathrm{n}=49)$

Megjegyzés: az ábrán feltüntettük az átlagok 95\%-os megbízhatósági intervallumát latban volt az aktuális és az álomsúly, az aktuális és a vágyott, valamint az aktuális és az elfogadható testsúly közötti százalékos eltéréssel (álomsúly: $\mathrm{r}=-0,41$; $\mathrm{p}=$ 0,005 ; vágyott testsúly: $\mathrm{r}=-0,42 ; \mathrm{p}=0,004$; elfogadható testsúly $=-0,42 ; \mathrm{p}=0,004)$. A célsúlyok alakulását a 4. ábra szemlélteti.

\section{Az evési magatartás változása}

$\mathrm{Az}$ ismételt méréses varianciaanalízis eredménye alapján a testsúlycsökkentő program során a kognitív korlátozás szignifikánsan növekedett $(\mathrm{F}[1,7 ; 75,3]=30,736$; $\mathrm{p}<0,001)$, a kontrollálatlan evésre $(\mathrm{F}[2,90]=16,548$; $\mathrm{p}<0,001)$ és az érzelmi evésre $(\mathrm{F}[2,90]=32,207$; $\mathrm{p}<0,001)$ való hajlam pedig szignifikánsan csökkent. $\mathrm{Az}$ utóelemzések eredményei alapján elmondható, hogy a fent leírt javulás az utánkövetés idején stabilan megmaradt mindhárom evési magatartás esetében. A kognitív korlátozás a program után egy évvel tendenciaszinten alacsonyabbnak bizonyult, a kontrollálatlan evés és az érzelmi evés tekintetében azonban nem mutatkozott szignifikáns visszaesés a program végéhez képest. A korrelációs elemzés alapján látható, hogy a program végére elért százalékos fogyás szignifikáns kapcsolatban volt az evés kognitív korlátozásának növekedésével $(\mathrm{r}=0,38 ; \mathrm{p}=$ $0,003)$, valamint a kontrollálatlan evés csökkenésével $(\mathrm{r}=0,31 \mathrm{l} ; \mathrm{p}=0,016)$. Az utánkövetés eredményei szerint az utánkövetés során felmért százalékos fogyás szignifikánsan összefüggött az evés kognitív korlátozásának növekedésével ( $\mathrm{r}=0,463 ; \mathrm{p}=0,001)$, valamint tendenciaszinten az érzelmi evés csökkenésével $(\mathrm{r}=0,286 ; \mathrm{p}=$ 0,051) (5. ábra). 


\section{Megbeszélés}

Prospektív, másfél éves időintervallumot felölelő kutatásunk tárgya az önsegítő elemekkel kiegészített kognitív viselkedésterápiás testsúlycsökkentő program hatékonyságának vizsgálata volt. Ennek során megvizsgáltuk a testsúly és a testsúlycélok alakulását, valamint az egészségmagatartásban (evési magatartás) bekövetkező változtatásokat. A fogyás tekintetében elmondható, hogy a 24 hetes program során a résztvevők közel 90\%-a ért el legalább 5-10 százalékos súlycsökkenést, amely a professzionális súlycsökkentő kezelések esetében a sikeres fogyás kritériuma. Ez a hatékonyság megfelel a hasonló kognitív viselkedésterápiás csoportok eredményeinek, melyekben 24 hét alatt átlagosan 7-10\%-os fogyás érhető el $[7,19]$.

A testsúlycélok tekintetében elmondható, hogy a testsúlycsökkentő csoportba jelentkezők irreális elvárásokkal érkeztek, aminek következtében azonban gyakran lebecsülik az elért fogyást, fekete-fehéren gondolkodva reménytelennek láthatják testsúlycéljaik elérését, kudarcaikat katasztrofizálják („Hiába fogytam 20 kg-ot, még mindig dagadt vagyok"). Mindez az elért testsúly megtartásához szükséges stratégiák (önmegfigyelés, testmozgás) feladásával is jár [29]. A résztvevők átlagosan a testsúlyuk 26-33\%-át szerették volna leadni (például 100 kg-ról kb. 70 kg-ra lefogyni) a 6 hónapos program végére, míg a 8\%-os fogyást csalódást keltőnek érezték, bár ez felel meg a leginkább egy kognitív viselkedésterápiás testsúlycsökkentő program során elérhető csökkenésnek. Ez egybecseng más kutatások eredményeivel [47], amelyek során hasonlóképpen azt találták, hogy a vizsgálati személyek irreális célsúlyokat állítottak maguk elé, amelyeket azután is fenntartottak, hogy tájékoztatták őket az elérhető fogyás mértékéről. A testsúlycsökkentő program megkezdését követően fél évvel a fogyás üteme rendszerint lelassul különféle környezeti, fiziológiai és pszichológiai hatások kölcsönhatásának következtében. Ekkor azonban a páciensek többsége még messze van az elérni kívánt testsúlytól, épp ezért komoly akadályt képezhetnek az irreális testsúlycélok, illetve fogyási elvárások, hiszen negatívan befolyásolják a személy testsúlyának további csökkenését és az elért testsúly megtartását [13]. Eszerint, ha a személy nem éri el a vágyott célt, az a súlycsökkentő próbálkozások feladásához és így visszahízáshoz vezethet. A fiatal, magasabb kezdő BMI-vel rendelkező nők hajlamosabbak a realitástól elrugaszkodott célok kitűzésére [23]; esetükben a lemorzsolódás aránya is nagyobb [24], ezért érdemes külön figyelmet fordítani rájuk a kezelés során.

Kutatásunkban azt találtuk, hogy a program során a résztvevők által kitûzött testsúlycélok mérséklődtek, reálisabbá váltak, és ez a tendencia megmaradt az utánkövetés során is. A kezelés során a fokozatosság, a kis lépésekben történő változtatás elve érvényesült, konkrét célsúlytartomány meghatározásával, a változást pedig folyamatosan monitoroztuk. Mindezek eredményekép- pen a program végére az elfogadható testsúly 10\%-os fogyásra mérséklődött, ami már megfelel a program során elérhető testsúlycsökkenés mértékének. A korrelációs elemzés eredményei szerint az aktuális súly és az álomsúly, az aktuális és a vágyott testsúly, valamint az aktuális és az elfogadható testsúly közötti százalékos eltérés is szignifikáns, fordított irányú kapcsolatban volt a program végére, valamint az utánkövetés végére elért fogyás százalékos mértékével. Mindez jól példázza, hogy a személyek minél irreálisabb célokat tűznek ki maguk elé az álomsúly, a vágyott súly és az elfogadható testsúly tekintetében, annál sikertelenebbek lesznek a kezelés során.

A reális célsúlyok kitűzését azonban nem minden kutatás támasztja alá: Calugi és mtsai [22] nem találtak kapcsolatot az irreális fogyási célok és a súlycsökkenés között a kognitív viselkedésterápiás csoportban részt vevők körében sem a program végén, sem hat hónappal később. Linde és mtsai [48] szerint ráadásul a nagyobb mértékű eltérés az álomsúly és az aktuális súly között nagyobb mértékű fogyással kapcsolódott össze. Saját kutatásunk Ohsiek és Williams [18] feltételezését támasztja alá, miszerint a reálisabb célsúlyok nagyobb mértékű fogyással jártak együtt a program végére, illetve az utánkövetés során. Nagy egyéni variabilitás mutatkozik tehát a tekintetben, hogy a résztvevők mennyire mérik fel reálisan az elérhető fogyás mértékét, így ennek már a jelentkezés során komoly figyelmet kell szentelni [29].

A kognitív viselkedésterápiás súlycsökkentő kezelés kiemelt célja az evési szokások javítása, amely kulcsfontosságú a sikeres testsúlykontroll szempontjából. Programunk során jelentős javulás volt tapasztalható az evési mintázat terén. Az evés tudatos korlátozására irányuló törekvés megnövekedett, míg a kontrollálatlan evés és az emocionális evés csökkent. Ezek a változások a program lezárása után egy évvel is szignifikánsak maradtak. A program során elért fogyás az evés kognitív korlátozásának növekedésével, valamint a kontrollálatlan evés csökkenésével szignifikáns összefüggést mutatott. Mindez a reálisabb testsúlycélok felállításával is kapcsolatban állhat. Az utánkövetés során mért fogyás pedig az evés kognitív korlátozásának növekedéséhez, valamint az érzelmi evés csökkenéséhez kapcsolódik.

A jelen kutatás számos korlátja közé tartozik az önszelektált mintavétel, valamint a minta relatíve alacsony elemszáma, ami csökkenti az alkalmazott próbák statisztikai erejét. A testsúlyra vonatkozó adatokat az utánkövetés során önbeszámolóval gyưjtöttük, amelyek validitása megkérdőjelezhető a résztvevők megfelelési igénye miatt. Annak lehetősége is felmerül, hogy azok a csoporttagok vettek részt az utánkövetésben nagyobb valószínúséggel, akik sikeresebben tudták tartani a testsúlyukat. Az életmódváltozók terén szélesebb körü felmérésre lett volna szükség, például a résztvevők által vezetett táplálkozási napló elemzésével pontos adatokat kaphattunk volna az elfogyasztott ételek és italok kalória- és tápanyagtartalmáról, illetve ezek alakulásáról, valamint a táplálkozási szokások megváltozásáról. 


\section{Következtetés}

Az elhízás növekvő prevalenciát mutat nemcsak világszerte, hanem hazánkban is, következményei miatt súlyos terheket ró mind az egyénre, mind a társadalomra. A kognitív viselkedésterápiás testsúlycsökkentő programok a bizonyítékalapú kezelési lehetőségek közé tartoznak, hazánkban azonban csak elvétve alkalmazzák, annak ellenére, hogy önmagában és más kezelés kiegészítéseként is hatékony intervenciónak tekinthető. Úgy véljük, eredményeink irányvonalat mutathatnak egy bizonyítékokon alapuló kognitív viselkedésterápiás testsúlycsökkentő módszer protokolljának szélesebb körü elterjesztéséhez. A résztvevők által kitűzött, irreálisan magas fogyási célok negatív hatással vannak a programban való részvételre, hiszen kifáradáshoz, motivációvesztéshez és a program feladásához vezethetnek. Épp ezért kulcsfontosságú a reális célok kitűzése már a kezdeti szakaszban, hiszen a megvalósítható testsúlycélok a fogyás sikerességével, a kezeléssel való együttmúködéssel, az elégedettséggel és legfóképpen egészségnyereséggel is együtt járnak.

Anyagi támogatás: A szerzők anyagi támogatásban nem részesültek.

Szerzôi munkamegosztás: A program adaptálása, a kutatás módszertanának kidolgozása, a kézirat megszövegezése: P.-F. D. és K. P. I. Csoportok vezetése: K. P. I. és V. G. A szakirodalmi összefoglaló elkészítése, az ábrák szerkesztése: K.-L. M. A kézirat kritikai átnézése: P.-F. D. és V. G. A cikk végleges változatát valamennyi szerző elolvasta és jóváhagyta.

Érdekeltségek: A szerzők kijelentik, hogy nincsenek érdekeltségeik.

\section{Köszönetnyilvánítás}

Köszönettel tartozunk $d r$. Czeglédi Editnek a statisztikában nyújtott segítségért, valamint munkatársainknak, közülük kiemelten Kresznerits Szilviának és dr. Virág Mártának értékes észrevételeikért, valamint a programban részt vevő összes személynek, akiktől sokat tanultunk, hogy az elhízás komplex problematikáját jobban megértsük.

\section{Irodalom}

[1] WHO (World Health Organization). Obesity and overweight, 2016. Available from: https://www.who.int/news-room/factsheets/detail/obesity-and-overweight [accessed: January 13 $2021]$.

[2] Carey M, Small H, Yoong SL, et al. Prevalence of comorbid depression and obesity in general practice: a cross-sectional survey. Br J Gen Pract. 2014; 64: el22-e127.

[3] Lo Coco G, Gullo S, Salerno L, et al. The association among interpersonal problems, binge behaviors, and self-esteem, in the assessment of obese individuals. Compr Psychiatry 2011; 52. $164-170$.
[4] Taylor VH, Forhan M, Vigod SN, et al. The impact of obesity on quality of life. Best Pract Res Clin Endocrinol Metab. 2013; 27: 139-146.

[5] Conradt M, Dierk JM, Schlumberger P, et al. Development of the weight- and body-related shame and guilt scale (WEB-SG) in a nonclinical sample of obese individuals. J Pers Assess. 2007; 88: 317-327.

[6] Puhl R, Brownell KD. Bias, discrimination, and obesity. Obes Res. 2011; 9: 788-805.

[7] Kohlné Papp I. Psychological characteristics of obesity: Sociocultural factors and psychotherapeutic possibilities of weight loss and weight maintenance. Doctoral dissertation, 2017. [Az obezitás pszichológiai jellemzői: szociokulturális hatások, a testsúlycsökkentés és súlymegtartás pszichoterápiás lehetőségei. Doktori értekezés, 2017.] Semmelweis Egyetem, Mentális Egészségtudományok Doktori Iskola, Budapest, 2017. [Hungarian]

[8] Sutin AR, Terracciano A. Perceived weight discrimination and obesity. PLoS ONE 2013; 8: e70048.

[9] Kiss N. The relationship between adolescent self-esteem and dissatisfaction with body image. Thesis, 2008. [A serdülókori önértékelés kapcsolata a testképpel való elégedetlenséggel. Szakdolgozat, 2008.] Eötvös Loránd Tudományegyetem, Pedagógiai és Pszichológiai Kar, Budapest, 2008. [Hungarian]

[10] Papp I, Czeglédi E, Túry F. The association between sociocultural effects and bias against obese people at preadolescence ages. [A szociokulturális hatások kapcsolata az elhízottakkal szembeni előítéletekkel kora serdülőkorban.] Mentálhig Pszichoszom. 2011; 12: 149-171. [Hungarian]

[11] Finucane MM, Stevens GA, Cowan, MJ, et al. National, regional, and global trends in body-mass index since 1980: systematic analysis of health examination surveys and epidemiological studies with 960 country-years and 9.1 million participants. Lancet 2011; 377: 557-567.

[12] Simonyi G, Medvegy M, Bedros, JR. (ed.) Obesitology in practice. [Obezitológia a praxisban: szakmai protokollal. Fókuszban a szimpatikus idegrendszer.] KM-PharmaMédia, Budapest, 2011. [Hungarian]

[13] Czeglédi E. Motivation for weight loss among weight loss treatment participants. [A fogyás motivációi súlycsökkentő kezelésben részt vevók körében.] Orv Hetil. 2017; 158: 1960-1967. [Hungarian]

[14] Dalle Grave R, Calugi S, Centis E, et al. Cognitive-behavioral strategies to increase the adherence to exercise in the management of obesity. J Obes. 2011; 2011: 348293.

[15] McKee H, Ntoumanis N, Smith B. Weight maintenance: Selfregulatory factors underpinning success and failure. Psychol Health 2013; 28: 1207-1223.

[16] Grave RD, Calugi S, Centis E, et al. Lifestyle modification in the management of the metabolic syndrome: achievements and challenges. Diabetes Metab Syndr Obes. 2010; 3: 373-385.

[17] Sasdelli AS, Petroni ML, Delli Paoli A, et al. Expected benefits and motivation to weight loss in relation to treatment outcomes in group-based cognitive-behavior therapy of obesity. Eat Weight Disord. 2018; 23: 205-214.

[18] Ohsiek S, Williams M. Psychological factors influencing weight loss maintenance: an integrative literature review. J Am Acad Nurse Pract. 2011; 23: 592-601.

[19] Dutton GR, Perri MG, Dancer-Brown M, et al. Weight loss goals of patients in a health maintenance organization. Eat Behav. 2010; 11: 74-78.

[20] Bray G, Look M, Ryan D. Treatment of the obese patient in primary care: targeting and meeting goals and expectations. Postgrad Med J. 2013; 125: 67-77.

[21] Pearson ES. Goal setting as a health behavior change strategy in overweight and obese adults: a systematic literature review examining intervention components. Patient Educ Couns. 2012; 87: $33-42$. 
[22] Calugi, S, Marchesini G, El Ghoch M, et al. The influence of weight-loss expectations on weight loss and of weight-loss satisfaction on weight maintenance in severe obesity. J Acad Nutr Diet. 2017; 117: 32-38.

[23] Heinberg LJ, Keating K, Simonelli L. Discrepancy between ideal and realistic goal weights in three bariatric procedures: who is likely to be unrealistic? Obes Surg. 2010; 20: 148-153.

[24] Dalle Grave R, Calugi S, Sartirana M, et al. Transdiagnostic cognitive behaviour therapy for adolescents with an eating disorder who are not underweight. Behav Res Ther. 2015; 73: 79-82.

[25] Lent MR, Vander Veur, SS, Peters JC, et al. Initial weight loss goals: have they changed and do they matter? Obes Sci Pract. 2016; 2: 154-161.

[26] Foster GD, Wadden TA, Vogt, RA, et al. What is a reasonable weight loss? Patients' expectations and evaluations of obesity treatment outcomes. J Consult Clin Psychol. 1997: 65: 79-85.

[27] Osunlana AM, Asselin J, Anderson R, et al. 5As Team obesity intervention in primary care: development and evaluation of shared decision making weight management tools. Clin Obes. 2015; 5: 219-225.

[28] Ames GE, Perri MG, Fox LD, et al. Changing weight-loss expectations: a randomized pilot study. Eat Behav. 2015; 6: 259-269.

[29] Kohlné Papp I, Perczel-Forintos D. How to lose weight consciously? - Cognitive behavioral workbook of a weight-loss program. [Hogyan fogyjunk tudatosan? - Munkafüzet kognitív viselkedésterápiás testsúlycsökkentő programhoz.] Oriold és Társai Kiadó, Budapest, 2020. [Hungarian]

[30] Teixeira PJ, Silva MN, Mata J, et al. Motivation, self-determination, and long-term weight control. Int J Behav Nutr Phys Act. 2012; 9: 22.

[31] Gow ML, Baur LA, Ho M, et al. Can early weight loss, eating behaviors and socioeconomic factors predict successful weight loss at 12- and 24-months in adolescents with obesity and insulin resistance participating in a randomised controlled trial? Int J Behav Nutr Phys Act. 2016; 13: 43.

[32] Raman J, Smith E, Hay P. The clinical obesity maintenance model: an integration of psychological constructs including mood, emotional regulation, disordered overeating, habitual cluster behaviours, health literacy and cognitive function. J Obes. 2013; 2013: 240128.

[33] Perczel-Forintos D. Mindfulness and self-reflection: the role of mindfulness interventions in the treatment of obesity. [Tudatosság és önreflexió: a mindfulness módszerek szerepe az elhízás kezelésében.] Mentálhig Pszichoszom. 2017; 18: 125-148. [Hungarian]

[34] Perczel-Forintos D. Cognitive behaviour therapy of obesity. In: Perczel-Forintos D, Mórotz K. (eds.) Cognitive behaviour therapy. 4th revised and expanded edition. [Kognitív viselkedésterápiás lehetőségek az elhízás kezelésében. In: PerczelForintos D, Mórotz K. (szerk.) Kognitív viselkedésterápia. 4. átdolgozott és bővített kiadás.] Medicina Könyvkiadó, Budapest, 2019; pp. 531-553. [Hungarian]

[35] Wadden TA, Butryn ML. Behavioral treatment of obesity. Endocrinol Metab Clin North Am. 2003; 32: 981-1003.
[36] Yumuk V, Tsigos C, Fried M, et al. Obesity Management Task Force of the European Association for the Study of Obesity. European Guidelines for Obesity Management in Adults. Obes Facts 2015; 8: 402-424. [Erratum: Obes Facts 2016; 9: 64.]

[37] Halmy L, Bíró Gy, Czinner A, et al. The obesity. In: Halmy L, Bíró Gy, Czinner A, et al. (eds.) Endocrinology - Metabolism. Guidance. Handbook of Clinical Guidelines. [Az elhízás. In: Halmy L, Bíró Gy, Czinner A, et al. (szerk.) Endokrinológia Anyagcsere. Útmutató. Klinikai Irányelvek Kézikönyve.] Medition Kiadó, Budapest, 2010; pp. 217-232. [Hungarian]

[38] Perczel-Forintos D, Czeglédi E. Cognitive and behavioral approaches in the treatment of obesity. In: Túry F, Pászthy B. (eds.) Current issues in the treatment of eating disorders. [Az elhízás kognitív (és) viselkedésterápiás megközelítési lehetőségei. In: Túry F, Pászthy B. (szerk.) Az evészavarok terápiájának aktuális kérdései.] Semmelweis Kiadó, Budapest, 2011; pp. 36-59. [Hungarian]

[39] Alimoradi M, Abdolahi M, Aryan L, et al. Cognitive behavioral therapy for treatment of adult obesity. Int J Med Rev. 2016; 3: 371-379.

[40] Butryn ML, Webb V, Wadden TA. Behavioral treatment of obesity. Psychiatr Clin North Am. 2011; 34: 841-859.

[41] Jacob A, Moullec G, Lavoie KL, et al. Impact of cognitive-behavioral interventions on weight loss and psychological outcomes: a meta-analysis. Health Psychol. 2018; 37: 417-432.

[42] Lv N, Azar KM, Rosas LG, et al. Behavioral lifestyle interventions for moderate and severe obesity: a systematic review. Prev Med. 2017; 100: 180-193.

[43] Papp I, Czeglédi E, Udvardy-Mészáros Á, et al. Outcome of a one year behavior therapy weight loss program. [A viselkedésterápia eredményeinek vizsgálata az elhízás kezelésében egy év távlatában.] Orv Hetil. 2014; 155: 1196-1202. [Hungarian]

[44] Cole TJ, Bellizzi MC, Flegal KM, et al. Establishing a standard definition for child overweight and obesity worldwide: international survey. BMJ 2000; 320: 1240.

[45] Cole TJ, Flegal KM, Nicholls D, et al. Body mass index cut offs to define thinness in children and adolescents: international survey. BMJ 2007; 335: 194.

[46] Karlsson J, Persson LO, Sjöström L, et al. Psychometric properties and factor structure of the Three-Factor Eating Questionnaire (TFEQ) in obese men and women. Results from the Swedish Obese Subjects (SOS) study. Int J Obes Relat Metab Disord. 2000; 24: 1715-1725.

[47] Mann T, de Ridder D, Fujita, K. Self-regulation of health behavior: social psychological approaches to goal setting and goal striving. Health Psychol. 2013; 32: 487-498.

[48] Linde JA, Jeffery RW, Finch EA, et al. Are unrealistic weight loss goals associated with outcomes for overweight women? Obes Res. 2004; 12: 569-576.

(Perczel-Forintos Dóra dr., e-mail: perczel-forintos.dora@med.semmelweis-univ.hu)

A cikk a Creative Commons Attribution 4.0 International License (https://creativecommons.org/licenses/by/4.0/) feltételei szerint publikált Open Access közlemény, melynek szellemében a cikk bármilyen médiumban szabadon felhasználható, megosztható és újraközölhető, feltéve, hogy az eredeti szerző és a közlés helye, illetve a CC License linkje és az esetlegesen végrehajtott módosítások feltüntetésre kerülnek. (SID_1) 